\title{
Science Applied for the Investigation of Imperial Gate from Eighteenth Century Wooden Church of Nicula Monastery
}

\author{
I. Bratu, ${ }^{1}$ Monk Siluan, ${ }^{2}$ C. Măruţoiu, ${ }^{3}$ I. Kacso, ${ }^{1}$ S. Garabagiu, ${ }^{1}$ V. C. Măruţoiu, ${ }^{3}$ \\ C. Tănăselia, ${ }^{4}$ D. Popescu, ${ }^{5}$ D. L. Postolache, ${ }^{6}$ and D. Pop ${ }^{7}$ \\ ${ }^{1}$ National Institute for Research and Development of Isotopic and Molecular Technologies, 67-103 Donat St., \\ 400293 Cluj-Napoca, Romania \\ ${ }^{2}$ Nicula Monastery, 407278 Cluj County, Romania \\ ${ }^{3}$ Faculty of Orthodox Theology, "Babes-Bolyai" University, Episcop Nicolae Ivan St., 400609 Cluj-Napoca, Romania \\ ${ }^{4}$ INCDO-INOE 2000 Research Institute for Analytical Instrumentation, 67 Donath St., 400293 Cluj-Napoca, Romania \\ ${ }^{5}$ Technical University of Cluj-Napoca, 28 Memorandumului St., 400114 Cluj-Napoca, Romania \\ ${ }^{6}$ Faculty of Orthodox Theology, University of Craiova, 13 Al. I. Cuza St., 200585 Craiova, Romania \\ ${ }^{7}$ University of Art and Design, 31 Unirii Square, 400098 Cluj-Napoca, Romania
}

Correspondence should be addressed to I. Bratu; ibratu@gmail.com, C. Măruţoiu; cmarutoiu@yahoo.com, and S. Garabagiu; sgarabagiu@itim-cj.ro

Received 17 August 2016; Revised 4 October 2016; Accepted 17 October 2016; Published 11 January 2017

Academic Editor: Vincenza Crupi

Copyright ( $\odot 2017$ I. Bratu et al. This is an open access article distributed under the Creative Commons Attribution License, which permits unrestricted use, distribution, and reproduction in any medium, provided the original work is properly cited.

Part of an indestructible component of any orthodox church, the Imperial Gates represent an important symbol in our cultural heritage. But in many cases the Imperial Gates from the wooden churches were damaged. In order to preserve and restore them, the scientific investigations of the Imperial Gate belonging to Nicula Monastery wooden church were performed by employing nondestructive and destructive methods. The wood essence was established, with its "health" status being investigated by FTIR (Fourier Transform Infrared) spectroscopy and DSC (Differential Scanning Calorimetry) thermal analysis. The painting materials employed by popular artists were determined by FTIR and XRF (X-ray fluorescence) spectroscopy as gypsum, calcite (rear background), lead white (Archangel Clothes), lead-minium (Archangel Clothes, leaf), iron oxide (Imperial Gate frame), malachite (green), Prussian blue (blue), orpiment (yellow), aliphatic, ester, and protein (probably egg yolk degradation products). Using similar colors as in the original artwork (resulting from the scientific investigation of the pigments) a 3D reconstruction has been performed. The restored Imperial Gates are placed in the old Nicula wooden church, being included into a tourist and religious circuit.

\section{Introduction}

Multidisciplinary investigations of church's wooden ceiling [1], dendrochronological studies [2], studies on timber species and provenance of wooden sculptures [3], studies of old Evangelical Church stall wood [4], and scientific studies on artworks [5] were reported. The wooden church from Nicula Monastery, Cluj County, Romania (see Supplementary Figure 1(A) in Supplementary Material available online at https://doi.org/10.1155/2017/6167856), was brought from the Nasal Fanate village in the year 1974. This wooden church was built in 1770 [6], although it seems to be older. On the wall that separates the nave from the narthex there is an inscription dated 1738 and it served as a parochial church in Goştila village, Blenchi parish, Salaj County. Around the year 1810, it is replaced by the new wall church after which it is sold to the Top village parish, near Gherla. In the year 1935 it is moved in Nasal Fanate village $[7,8]$. The sanctuary is built out of oak timbers and is characterized by a rectangular shaped plan, divided into narthex, nave, and altar. The entry door in the church is decorated with rosettes, which together form crosses. The decor is made with incisions which creates the impression of stars. The door is composed of three pieces of wood, fastened together in diagonal with nails, 


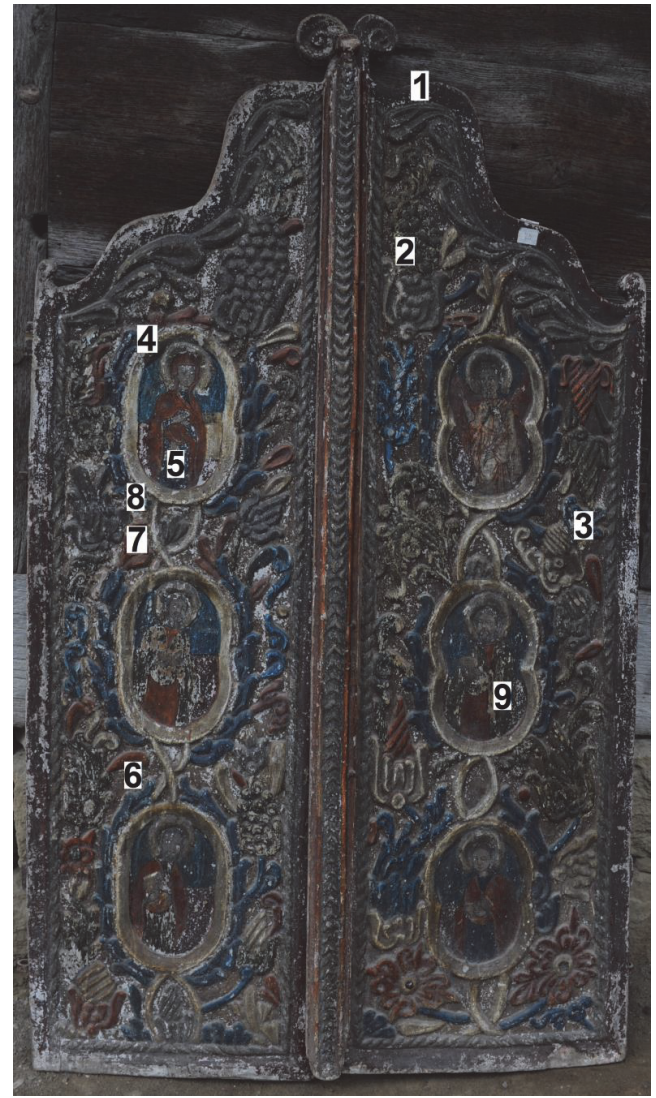

(a)

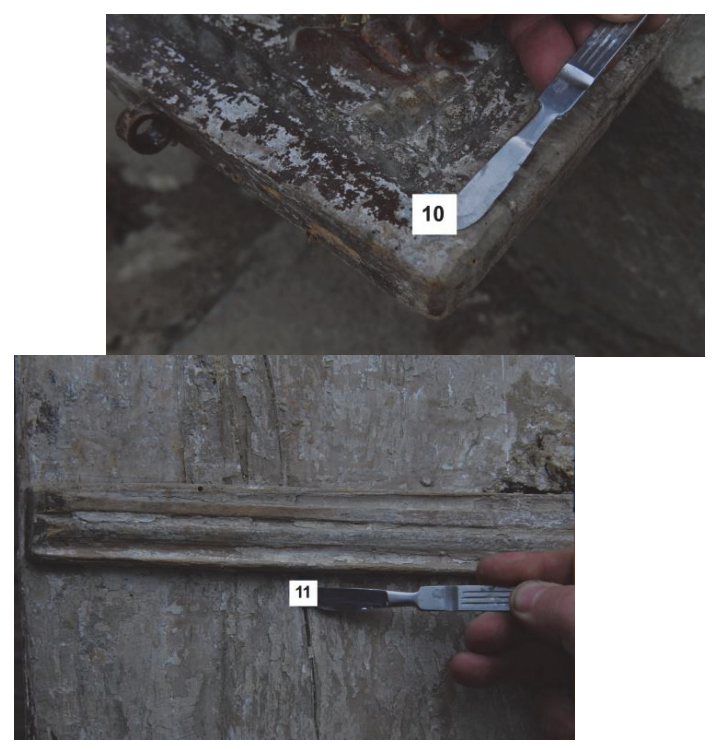

(b)

FIGURE 1: (a) Imperial Gates of the wooden church and some sampling points. (b) Imperial Gates of the wooden church (rear side) and two sampling points.

with numerous metal decorations and a metal handle. The passageway from the narthex to the nave is decorated, in the upper side with slight rounding, while the side parts are marked off in the exterior with a rope-shaped strap. In the same type of decoration, above the entry, a cross is shaped together with the elongated horizontal arm. On the sides, rosettes are decorated on a star background, in the upper and lower registry. The wall that separates the narthex from the nave is a continuous one and has the only marks from the painted decor of the church. The nave of the church, which is covered by a semicylinder arch, has a maximum height of $3.65 \mathrm{~m}$, as opposed to the narthex which has a height of $1.90 \mathrm{~m}$. In the nave, between the south and the north walls of the church, there is a tie beam (at $1.45 \mathrm{~m}$ from the nave and narthex wall). The passageway between the nave and the altar apse is made through two spaces, a larger one, with a height of $1.45 \mathrm{~m}$ and a width of $0.80 \mathrm{~m}$, destined for the heavenly doors, and a smaller one, destined for the deacon doors, with a height of $1.55 \mathrm{~m}$ and a width of $0.5 \mathrm{~m}$. The altarpiece is not composed of a continuous wall but has a semicircular mouth in the central area. In the apse, the arch of the altar is sustained, towards the altarpiece, by a rounded grain which follows the edge of the altar's arch.
The aim of this paper was to investigate the painting materials employed for the Imperial Gates of the Nicula wooden church by several methods such as X-ray fluorescence and FTIR spectroscopy, DSC, and 3D scanning techniques [9-14]. The wood species employed and its conservation status were also investigated. Digital reconstruction of Imperial Gates is an approach that is based on reverse engineering method and well-known image processing methods. Digital restoration may lead to two results: (i) restored Imperial Gate in a similar way with classic method but in digital 3D format and (ii) digital 3D model of Imperial Gates restored to its initial form both for painted layer and for support of wood. There are many digital reconstruction methods [15-19] which use laser scanning as tool for digitization because the accuracy is superior to other methods.

\section{Materials and Methods}

The Imperial Gates (Figures 1(a) and 1(b)) of the altarpiece within the wooden church of Nicula Monastery have six medallions. In the first registry the first two medallions are painted with the Virgin Mary and Gabriel. The other four medallions, from the second and third registry, represent 


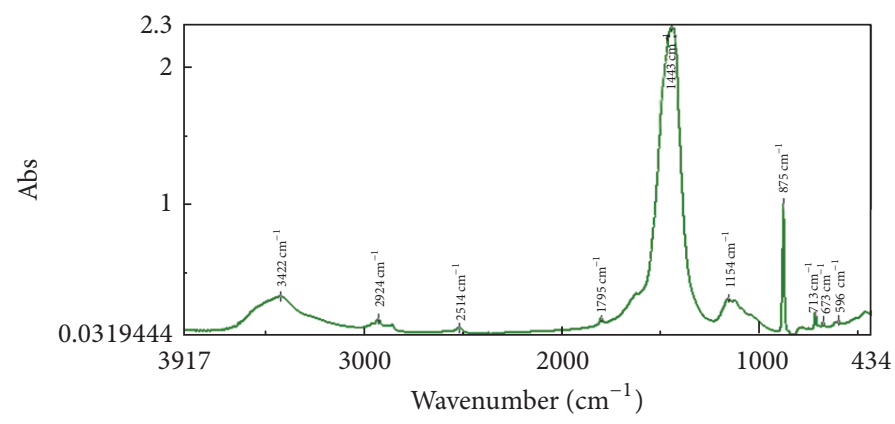

FIGURE 2: FTIR spectrum of the Imperial Gate (IG) rear background.

the four evangelists: Mark, Matthias, Joan, and Luca. The backgrounds of the medallions are adorned with sculptures showing off numerous traditional motifs like the rope, grape vine, and the rosette. The predominant colors of red and blue are visible, as a symbol of Messianic royalty.

Small quantities of the painting materials, having various colors, and wood samples have been collected by an authorized conservation and restoration specialist in order to be analyzed using FTIR spectroscopy. The samples (both painting materials and wood samples) were ground in an agate mortar till an extra fine texture is obtained and then included into $\mathrm{KBr}$ pellets ( $\mathrm{KBr}$ pure spectral powder, purchased from Sigma-Aldrich). FTIR spectra have been registered with a resolution of $4 \mathrm{~cm}^{-1}$ using a JASCO 6100 FTIR spectrometer (with Globar source and TGS detector at room temperature) in the 4000 to $400 \mathrm{~cm}^{-1}$ spectral domain by employing $\mathrm{KBr}$ pellet technique. The spectra were processed by Spectral Analysis software.

The white labels and the corresponding number for each painting material sample are presented in Figures 1(a) and 1(b). X-ray fluorescence measurements were performed using an INNOV-X Alpha-6500 portable instrument; see Supplementary Figure 2 (wolfram anode: $35 \mathrm{kV}$ voltage, $15 \mu \mathrm{A}$ intensity, $3 \mathrm{~mm}$ filter, Be window, 2-square $\mathrm{mm}$ spot size, and PIN Si detector). Integration time was set for 60 seconds, in two consecutive runs of 30 seconds each.

Differential Scanning Calorimetry (DSC) was carried out by means of a Shimadzu DSC-60 calorimeter, the sample $\left(\sim 2 \mathrm{mg}\right.$ ) being heated in the range of $20-550^{\circ} \mathrm{C}$ with a heating rate of $10^{\circ} \mathrm{C} / \mathrm{min}$ in crimped aluminum sample cell. The analysis was performed in static air atmosphere.

In the case presented in this paper for digitization we used two types of equipment: a 3D laser scanner which is able to acquire both 3D shape and texture of Imperial Gates and a photo camera with 20-megapixel sensor for image acquisition. The results obtained after data acquisition stage are 3D model, texture UV Map format, and high resolution photo resulting from combining multiple photos; in our case the image is $3800 \times 12000$ pixels.

\section{Results and Discussion}

3.1. XRF Pigment Analysis. The results of the XRF investigations are synthesized in Supplementary Table 1. XRF quantitative data were provided by manufacturer's software

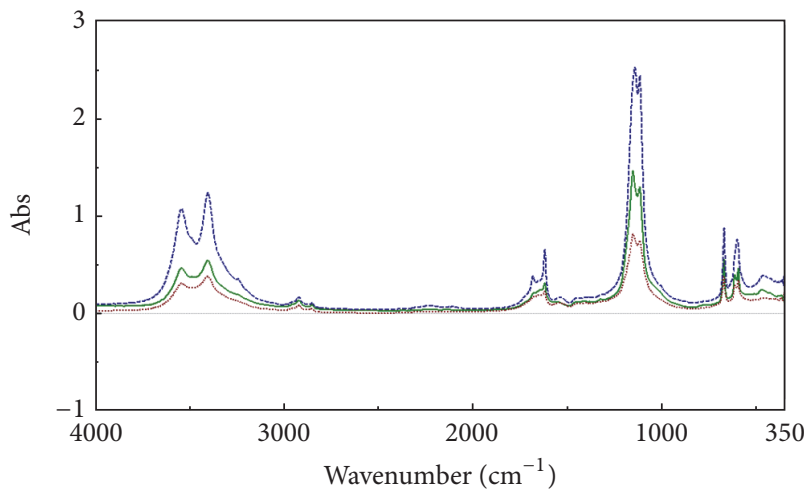

FIGURE 3: FTIR spectrum of red border (solid line) and of blue (dashed line) and of yellow (dot line) painting materials.

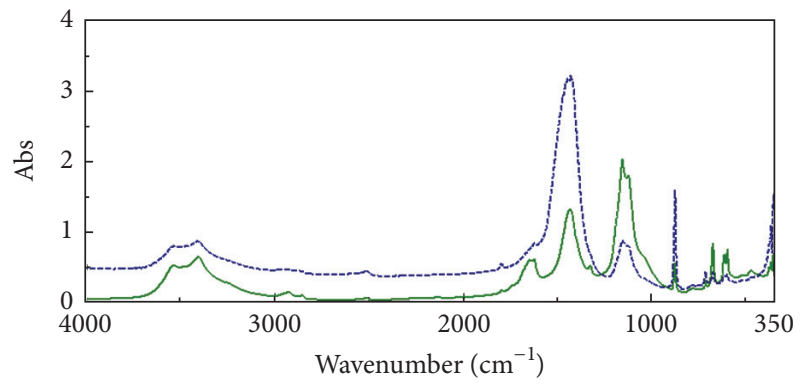

FIGURE 4: FTIR spectrum of two samples collected from the Imperial Gates: solid line, IG_10; dashed line, IG_11.

package. Inserting XRF spectra or exporting graphical files (CSV) from the software does not have the resolution needed to interpret the results directly from the graph itself. We rely on the numerical values offered by the software. Cobalt results were below detection limit and were not reported.

Based on XRF analysis results one can propose the composition of the employed painting materials as leadminium $\left(\mathrm{Pb}_{3} \mathrm{O}_{4}\right)$, AsS (realgar), and $\mathrm{Fe}_{2} \mathrm{O}_{3}$ for red; malachite for green; cobaltite (CoAsS) or smaltite $\left(\mathrm{CoAs}_{2}\right)$ for blue; lead carbonate $\left(\mathrm{PbCO}_{3}\right)$ for white; and $\mathrm{As}_{2} \mathrm{~S}_{3}$ (orpiment) for yellow.

3.2. FTIR Spectroscopy. FTIR spectra of different painting materials are presented in Figures 2-5. 


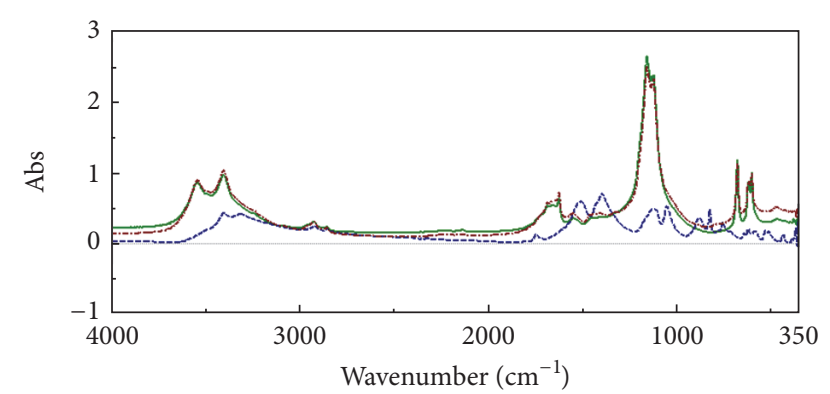

FIGURE 5: FTIR spectra of green two painting materials: solid line, IG_5 sample; dashed line, malachite; dash-dot line, IG_6 sample.

For IG_11 sample rear background the composition is calcium carbonate $\left(1443\right.$ and $875 \mathrm{~cm}^{-1}$ ) as major component and gypsum $\left(3442,1154\right.$, and $\left.596 \mathrm{~cm}^{-1}\right)$ as minor component.

For red border, the painting materials composition is lead-minium and gypsum.

As compared to XRF data, one can propose smaltite, (Co,Fe,Ni)As $\mathrm{As}_{2}$, (or cobaltite-CoAsS) for blue, taking into account the good collaboration of the local artists with the pigments' merchants from Bohemia. One can eliminate azurite by comparing our FTIR spectrum with azurite one from RRUFF databank.

Sample 10 contains probably more $\mathrm{PbCO}_{3}$, then $\mathrm{CaCO}_{3}$ (and barium sulfate), and gypsum, whereas sample 11 contains more $\mathrm{CaCO}_{3}$ (and barium sulfate), then $\mathrm{PbCO}_{3}$, and gypsum. Samples 10 and 11 contain quartz traces, with a shoulder at $\sim 1033 \mathrm{~cm}^{-1}$ being visible, also.

Besides gypsum, present in all painting materials, malachite could be a good component for green painting material. $\mathrm{XRF}$ data showed that $\mathrm{Cu}$ is major element; we proposed then malachite as green pigment; see Figure 5. Verdigris and azurite can be eliminated as green pigments by comparing their FTIR spectra (RRUFF databank) with the experimental one.

3.3. Wood Species Identification and "State of Conservation". FTIR spectra of wooden samples collected from the Imperial Gates compared to standard lime species are presented in Figure 6. FTIR spectroscopy is an adequate technique for studying wood components and also the changes that appear in spectra due to the modifications that appear in these spectra due to different treatments such as oldness, oxidation, and thermal degrading [20]. Based on FTIR spectra analysis one can identify the specific vibrations of various wood components such as lignin or cellulose.

One can sustain that lime is the wood species employed for these Imperial Gates taking into account the similarities of the FTIR spectra, especially in the (3000-2700) and (2000400) $\mathrm{cm}^{-1}$ spectral domains.

For analyzing the wood conservation state of the Nicula Imperial Gates, some parameters were determined as follows: the crystallinity indexes, defined [21] as $I_{\mathrm{crl}}=A_{1377} / A_{669}$, $I_{\mathrm{cr} 2}=A_{1109} / A_{690}$, or TCI $=A_{1378} / A_{2925}$ (Total Crystallinity Index) and LOI $=A_{1426} / A_{895}$ (Lateral Order Index), with A being the absorbance of each corresponding absorption

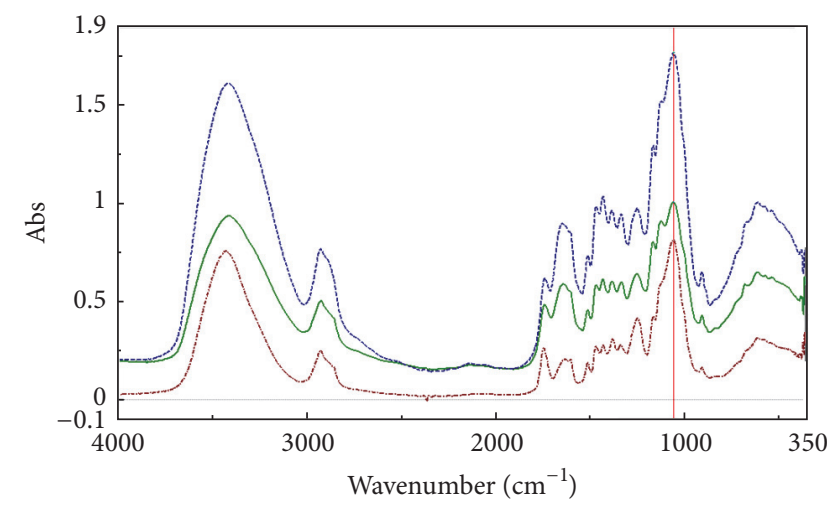

FIGURE 6: FTIR spectra of Imperial Gates wood species as compared to lime species: solid line, historical up wooden stand; dashed line, Imperial Gates wood; dash-dot line, lime wood standard.

band maximum. Different lignin to cellulose ratios, defined [22] as $(\mathrm{L} / \mathrm{C})_{1}=A_{1506} / A_{1738},(\mathrm{~L} / \mathrm{C})_{2}=A_{1506} / A_{1158}$ or $(\mathrm{L} / \mathrm{C})_{3}=A_{1506} / A_{895}$, and $(\mathrm{L} / \mathrm{C})_{4}=A_{1506} / A_{1377}$, were employed. These definitions can be used only as an indication of their change during time. Table 1 contains these ratios for historical and modern lime wood species.

The crystallinity is decreased for historical lime wood as compared to modern one; see the corresponding values from Table 1. Consequently, the amorphous content is increased for historical lime wood as compared to modern lime wood; see Table 1 . The cellulose content is decreased in time more rapidly than lignin one for this wood species; that is, the cellulose consumption is faster in time than lignin one; see $(\mathrm{L} / \mathrm{C})_{1}$ and $(\mathrm{L} / \mathrm{C})_{3}$ ratios behavior. As concerning up wooden support, one can see that the crystallinity decreases in time whereas the $\mathrm{L} / \mathrm{C}$ ratio is increased as a consequence of cellulose consumption.

3.4. Differential Scanning Calorimetry. Two exotherms were observed in the DSC curves of standard lime wood at 330 and $440^{\circ} \mathrm{C}$ (see Figure 7) being assigned to the thermooxidation of amorphous polysaccharides (predominantly cellulose) and of lignin and polysaccharides mixtures, respectively [23, 24].

The maximum temperature of the characteristic peaks increases with $\sim 15^{\circ} \mathrm{C}$ [25], slight widening of the peaks due to the decrease of the crystallinity [21] and the increase of lignin/cellulose ratio [24] for the Imperial Gates' wood during time was also observed (i.e., the cellulose consumption in time is faster than lignin one). All these changes, according to the already mentioned literature data, confirm that the wood stage of the Nicula Imperial Gates is lime one.

3.5. 3D Restoration. The digital restoration of the Imperial Gates is done in four steps.

(1) Digitization of Imperial Gates: in this phase, we use different techniques to obtain the $3 \mathrm{D}$ model of Imperial Gate.

(2) Digital restoration of wood support: using CAD software (Catia V5), the wood support is restored and completed with the missing parts. 
TABLE 1: Conservation state of lime wooden samples.

\begin{tabular}{lcccccccc}
\hline Sample & $I_{\mathrm{cr}}^{1}$ & $I_{\mathrm{cr}}^{2}$ & TCI & LOI & $(\mathrm{L} / \mathrm{C})_{1}$ & $(\mathrm{~L} / \mathrm{C})_{2}$ & $(\mathrm{~L} / \mathrm{C})_{3}$ & $(\mathrm{~L} / \mathrm{C})_{4}$ \\
\hline Historical wooden stand & 1.07 & 0.98 & 1.26 & 0.59 & 1.19 & 0.57 & 1.13 & 0.76 \\
Historical up wooden stand & 1.02 & 0.71 & 1.19 & 0.43 & 0.93 & 0.56 & 1.05 & 0.75 \\
Modern lime wood & 1.21 & 3.11 & 1.25 & 1.71 & 0.71 & 0.44 & 1.15 \\
\hline
\end{tabular}

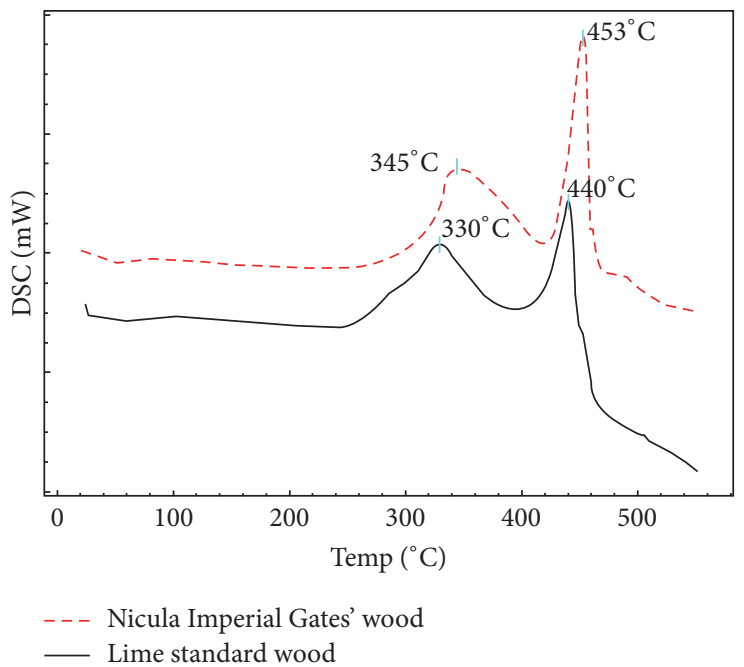

FIgURE 7: DSC curves of Nicula Imperial Gates and of lime species standard wood.

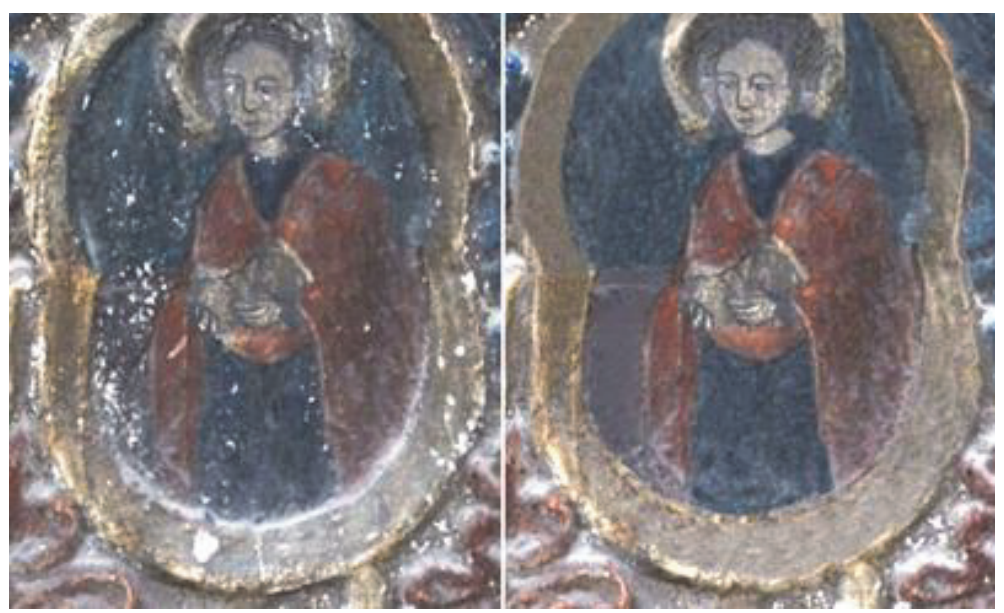

FIGURE 8: The restoration of the painted layer with the current colors.

(3) Digital restoration of painted layer I: using photo editing software, the painted layer is restored to the actual stage.

(4) Digital restoration of painted layer II: using results from XRF and FTIR, the painted layer is restored with the original colors.

After digital restoration process is completed, the two components are assembled into a 3D model that can be used in web dissemination of the cultural heritage assets.

In first stage digitization of the Imperial Gates was done using two different methods: laser scanning and photogrammetry. We obtain two different 3D models (see Supplementary Figure 9); the model obtained using the laser scanning operation is very accurate and it had required a high amount of processing power hard disk space, while the other model obtained using photogrammetry is less accurate but it has the visual appearance almost identical with the Imperial Gates and it requires a much lower amount of resources for visualization.

The 3D models obtained using the two methods of $3 \mathrm{D}$ digitization are in the form of a triangular mesh (see Figure 8 right); this mesh is processed in order to obtain a CAD surface; the CAD surface is used to create the solid 
body of the Imperial Gates. After a primary digitization step, the mesh is processed (Supplementary Figure 10) in order to correct superficial errors of the scanned geometry of the Imperial Gates. The next digital restoration step of the wooden support involves the 3D computer aided design modeling of the missing parts and their assembly with the 3D solid body model of the Imperial Gates.

In the restoration of the painted layer we can have two distinct situations: the restoration with the current colors (see Figure 8) and restoration with the original color.

Having the painted layer digitally restored and the wooden support 3D model fully assembled with all the missing elements, the final composition for the whole digitally reconstructed 3D model can be assembled. Depending on the final destination and purpose of the 3D model, we can have two situations.

The first one involves the creation of a high definition 3D digital model using the model obtained using the laser scanning equipment and using the painted layer. This 3D model can be used in the 3D digital documentation and further analysis of the restoration process since its geometry is highly accurate and it represents the real object with very high fidelity.

The second situation involves the creation of a low definition 3D model that uses the mesh obtained from the photogrammetry $3 \mathrm{D}$ digitization process and it is textured with the digitally restored paint layer. This model is best suited for online dissemination since the file size will be optimized for in browser visualization and the required computer resources needed for this process are not too high allowing a higher number of potential users to have access to this 3D model.

Taking into account all these investigations, the Imperial Gates were preserved and restored by specialists and the result of these processes is presented in Figure 9.

\section{Conclusions}

Based on the XRF and FTIR spectroscopy the painting materials employed as painting materials for Imperial Gates are lead-minium, AsS (realgar) and $\mathrm{Fe}_{2} \mathrm{O}_{3}$ for red; cobaltite or smaltite for blue; malachite for green; lead carbonate for white; $\mathrm{As}_{2} \mathrm{~S}_{3}$ for yellow; and $\mathrm{PbCO}_{3}, \mathrm{CaCO}_{3}$, and gypsum as background and for white color. FTIR and DSC measurements conclude that lime is the wood species employed for Imperial Gates. Its conservation status, taking into account the increase of the amorphous content, is established by FTIR analyses that sustained a decrease of the lime wood crystallinity during time; increased consumption of cellulose was also established. Digital restoration of Imperial Gates can be a solution for digital preservation of this part of our cultural heritage. Using low definition 3D model the dissemination of Imperial Gates can be done using web distribution and also mobile compatible format. An example of web distribution can be seen on the project website: http://usiimparatesti.granturi.ubbcluj.ro/3D.html. The Imperial Gates were preserved and restored; now they were placed

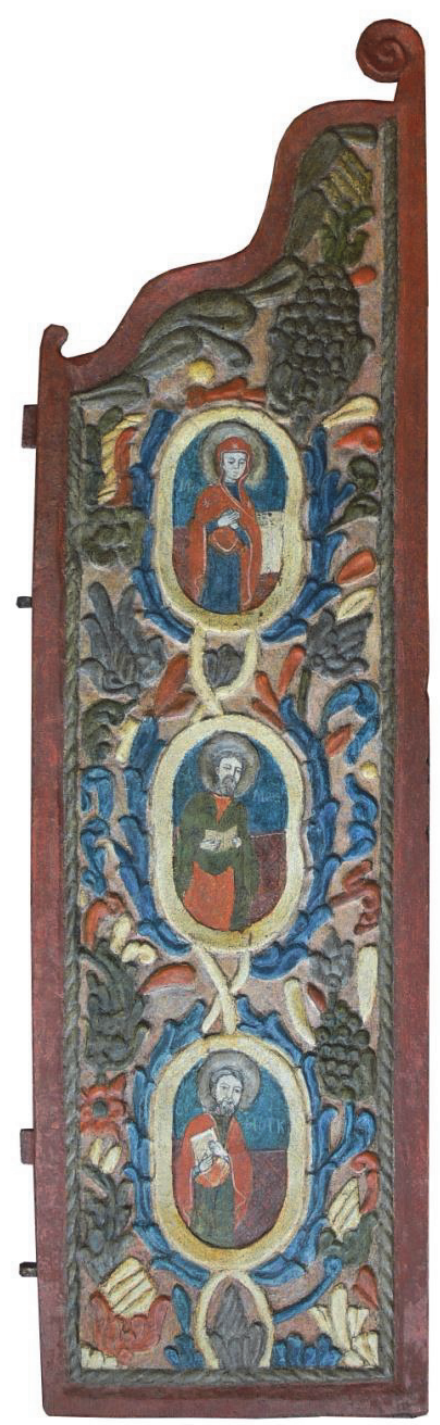

FIGURE 9: Restored Imperial Gate (left side) of Nicula wooden church Imperial Gates.

in the Nicula old wooden church being included into a tourist and religious circuit.

\section{Disclosure}

I. Bratu and C. Măruţoiu are co-first authors.

\section{Competing Interests}

The authors declare that there is no conflict of interests regarding the publication of this paper.

\section{Acknowledgments}

The financial support of PN II-PT-PCCA-2013-4-1882 project is greatly acknowledged. 


\section{References}

[1] M. L. Saladino, S. Ridolfi, I. Carocci, G. Chirco, S. Caramanna, and E. Caponetti, "A multi-disciplinary investigation of the 'Tavolette fuori posto' of the 'Hall of Barons' wooden ceiling of the 'Steri' (Palermo, Italy)," Microchemical Journal, vol. 126, pp. 132-137, 2016.

[2] D. R. Brothwell and A. M. Pollard, Eds., The Handbook of Archaeological Sciences, John Wiley \& Sons, London, UK, 2001.

[3] N. Macchioni, G. M. Fachechi, S. Lazzeri, and L. Sozzi, “Timber species and provenances of wooden sculptures. Information from the collections of the National Museum of 'Palazzo di Venezia' in Rome," Journal of Cultural Heritage, vol. 16, no. 1, pp. 57-64, 2015.

[4] C. Marutoiu, S. P. Grapini, A. Baciu et al., "Scientific investigations of a 16th century stall belonging to the evangelic church in Bistriţa, Bistriţa-Năsăud County, Romania," Journal of Spectroscopy, vol. 2013, Article ID 957456, 5 pages, 2013.

[5] V. Lee and D. Attinger, "Thermodynamics and historical relevance of a jetting thermometer made of Chinese zisha ceramic," Scientific Reports, vol. 6, article 28609, 2016.

[6] S. Pascu, V. Vătăşeanu, M. Porumb et al., Monumente Istorice şi de Artă Religioasă din Arhiepiscopia Vadului, Feleacului şi Clujului, Editată de Arhiepiscopia Vadului, Felecului şi Clujului, Cluj-Napoca, Romania, 1982.

[7] D. Arhim Cobzaru, The Monography of the Assumption Monastery, Ecllesia Publishing, Nicula, Romania, 2010.

[8] A. Tudor and V. Tudor, Goştila 6003, Monography, Editura Astra, Dej, 2007.

[9] C. Măruţoiu, I. Bratu, L. Troşan et al., "Scientific investigation of the Imperial Gates belonging to the wooden church from Səcel, Turda County, Romania," Spectrochimica Acta-Part A: Molecular and Biomolecular Spectroscopy, vol. 152, pp. 311-317, 2016.

[10] I. Bratu, C. Măruțoiu, L. Troșan, Z. Moldovan, I. Kacso, and D. Toader, "Complex investigation of component materials of triptych icon 'Mother of God' from the patrimony of Ethnographic Museum of Transylvania," Revue Roumaine de Chimie, vol. 59, no. 11-12, pp. 1003-1008, 2014.

[11] C. Marutoiu, I. Bratu, A. M. Budu et al., "Evaluation of conservation state by analysis of imperial gates' constituent materials belonging to A Aschileu Mic Wooden Church, Cluj County," Revista de Chimie, vol. 66, no. 7, pp. 992-996, 2015.

[12] C. Măruţoiu, I. Bratu, A. Trifa, M. Botiş, and V. C. Măruţoiu, "Ftir analysis of painting materials from the Church Saint Paraschiva, of Poienile Izei, Maramureş, Romania," International Journal of Conservation Science, vol. 2, no. 1, pp. 29-35, 2011.

[13] A. Baciu, Z. Moldovan, I. Bratu et al., "Comparative study of the painting materials of a series of orthodox icons on wooden and glass support from Transylvania," Current Analytical Chemistry, vol. 6, no. 1, pp. 53-59, 2010.

[14] J. J. Lucejko, F. Modugno, E. Ribechini, D. Tamburini, and M. P. Colombini, "Analytical instrumental techniques to study archaeologicalwood degradation," Applied Spectroscopy Reviews, vol. 50, no. 7, pp. 584-625, 2015.

[15] J. Wang, D. Gu, Z. Yu, C. Tan, and L. Zhou, "A framework for 3D model reconstruction in reverse engineering," Computers and Industrial Engineering, vol. 63, no. 4, pp. 1189-1200, 2012.

[16] C. Neamtu, D. Popescu, R. Mateescu, D. Hurgoiu, and P. Pupeză, "Reconstruction of ceramic vessels from the family of chiup," in Quality and Innovation in Engineering and Management, S. Popescu, S. Brad, and D. Popescu, Eds., pp. 467-470, Technical University of Cluj-Napoca, Cluj-Napoca, Romania, 2011.

[17] C. Neamţu, Z. Buna, R. Mateescu, F. Popister, and X. Morar, "CAD software in 3D reconstructions of ancient world," Quality-Access to Success, vol. 13, supplement 5, pp. 513-518, 2012.

[18] V. Domiter, B. Repnik, B. Žalik, A. Sadžak, and S. Rizvić, "Surface reconstruction algorithms in cultural heritage digital representation," in Proceedings of the 22nd International Symposium on Information, Communication and Automation Technologies (ICAT '09), Sarajevo, Bosnia, October 2009.

[19] R. Comes, C. Neamţu, Z. Buna, I. Badiu, and P. Pupeză, "Methodology to create 3D models for augmented reality applications using scanned point clouds," Mediterranean Archaeology \& Archaeometry, vol. 14, no. 4, pp. 35-44, 2014.

[20] X. Colom, F. Carrillo, F. Nogués, and P. Garriga, "Structural analysis of photodegraded wood by means of FTIR spectroscopy," Polymer Degradation and Stability, vol. 80, no. 3, pp. 543-549, 2003.

[21] C. M. Popescu, Y. Sakara, M. C. Popescu, A. Osaka, and C. Vasile, "Degradation of lime wood painting supports," $e$ Preservation Science, vol. 2, pp. 19-29, 2005.

[22] C.-M. Popescu, M.-C. Popescu, and C. Vasile, "Structural analysis of photodegraded lime wood by means of FT-IR and 2D IR correlation spectroscopy," International Journal of Biological Macromolecules, vol. 48, no. 4, pp. 667-675, 2011.

[23] S.-I. Tsujiyama and A. Miyamori, "Assignment of DSC thermograms of wood and its components," Thermochimica Acta, vol. 351, no. 1-2, pp. 177-181, 2000.

[24] P. Budrugeac and A. Emandi, "The use of thermal analysis methods for conservation state determination of historical and/ or cultural objects manufactured from lime tree wood," Journal of Thermal Analysis and Calorimetry, vol. 101, no. 3, pp. 881-886, 2010.

[25] I. C. A. Sandu, M. Brebu, C. Luca, I. Sandu, and C. Vasile, "Thermogravimetric study on the ageing of lime wood supports of old paintings," Polymer Degradation and Stability, vol. 80, no. 1, pp. 83-91, 2003. 

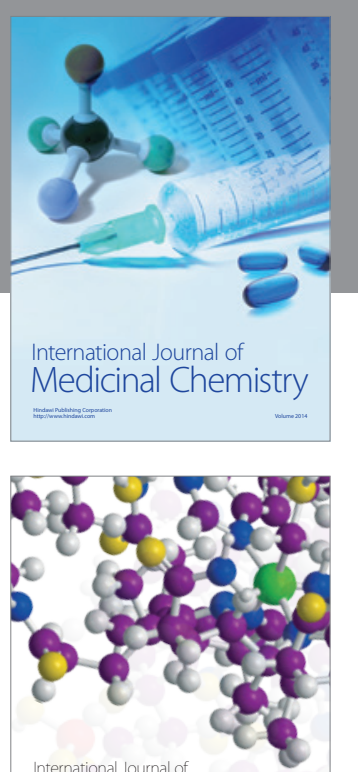

Carbohydrate Chemistry

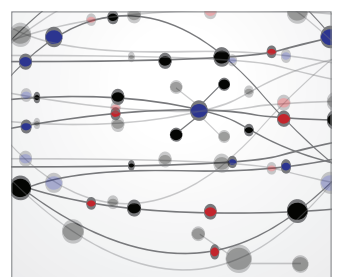

The Scientific World Journal
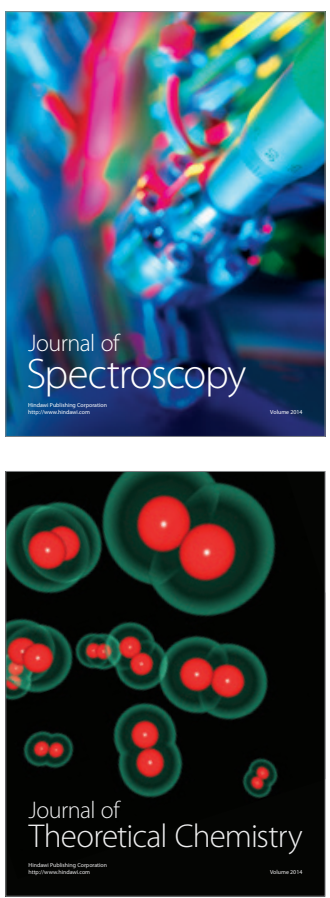
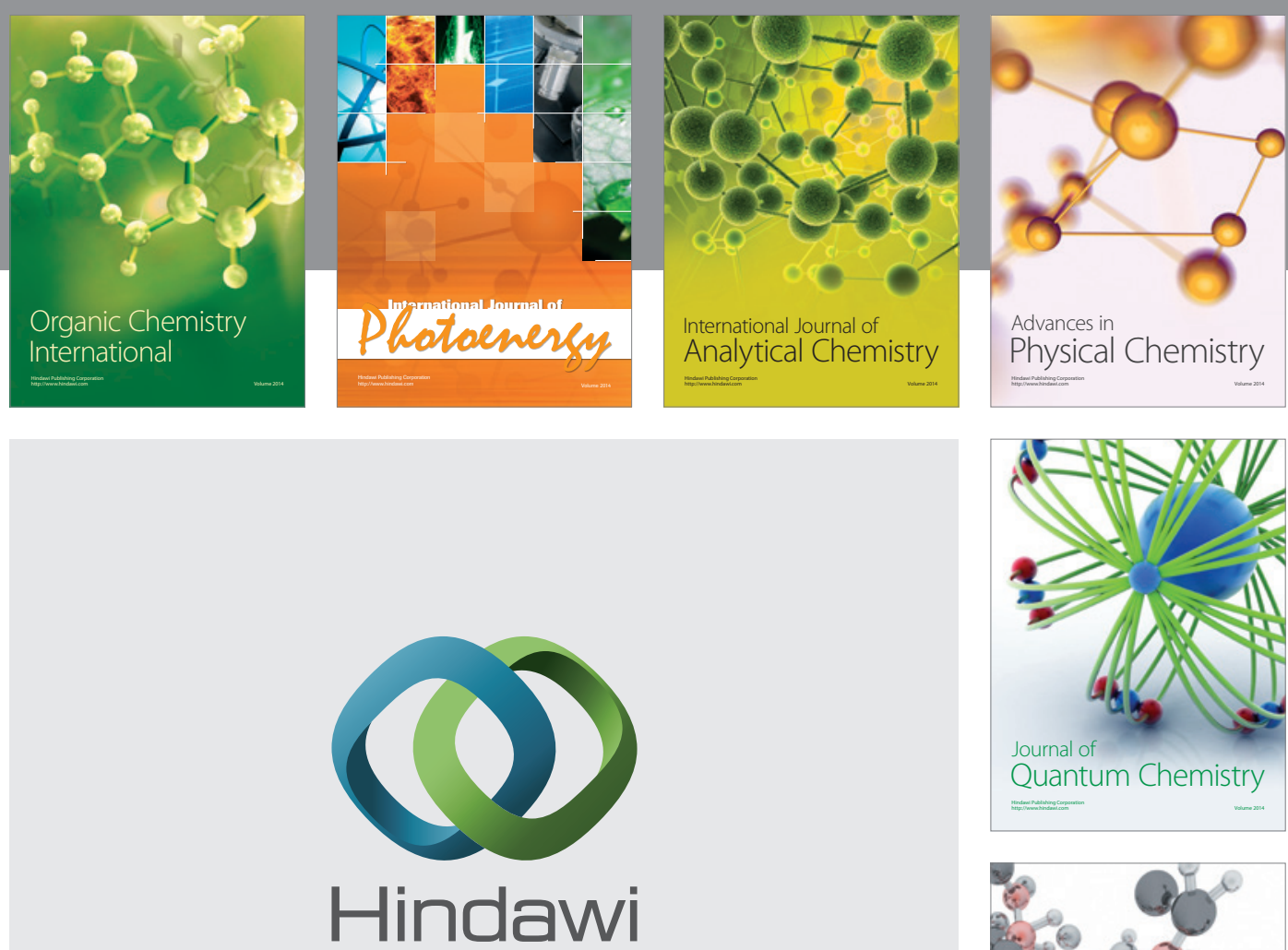

Submit your manuscripts at

https://www.hindawi.com

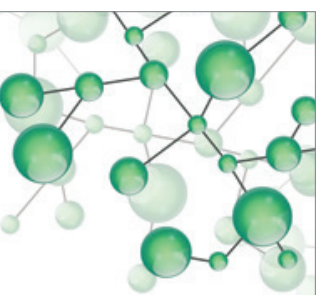

International Journal of

Inorganic Chemistry
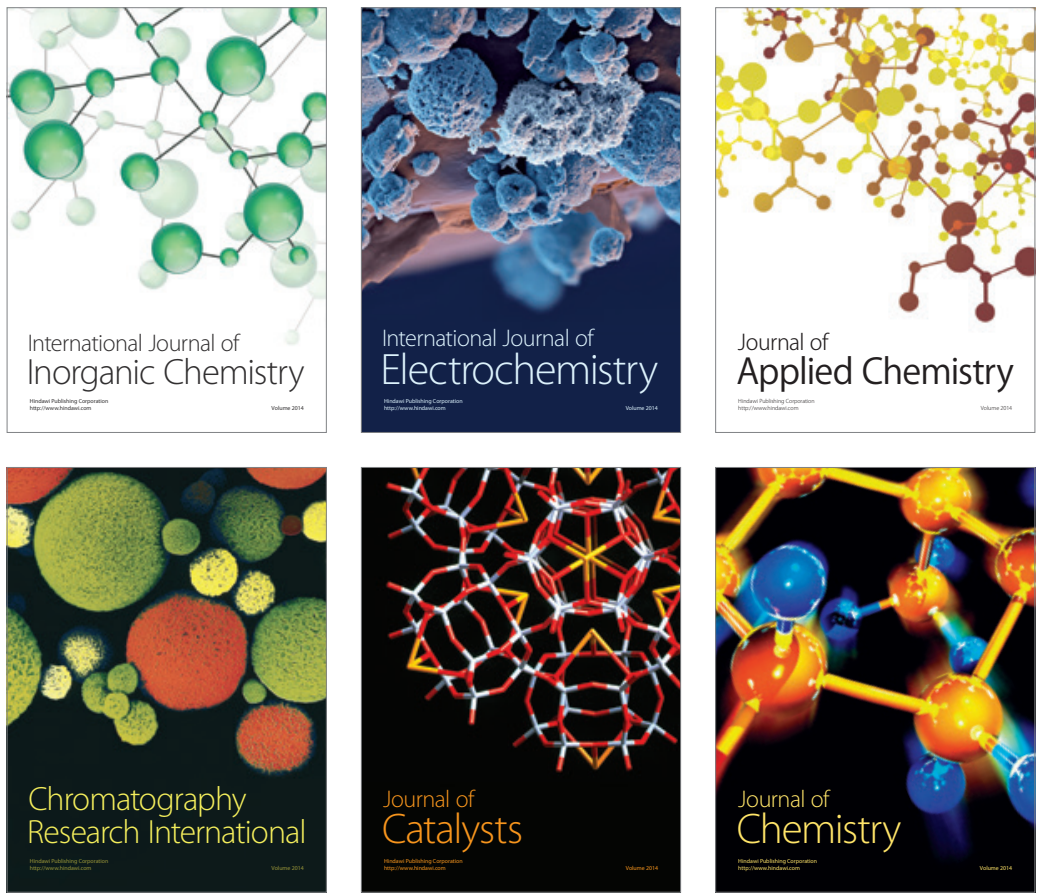

Journal of

Applied Chemistry
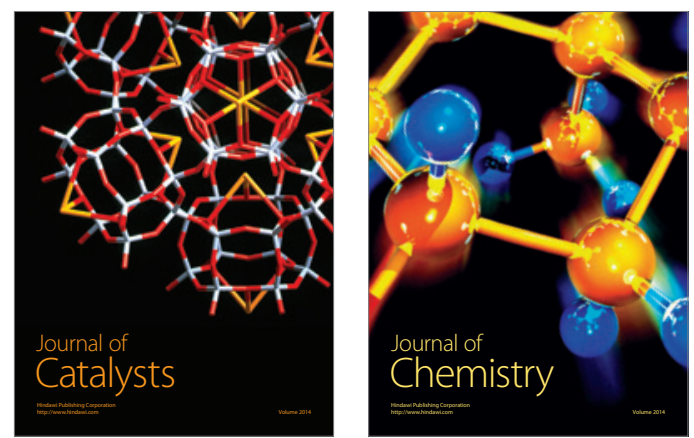
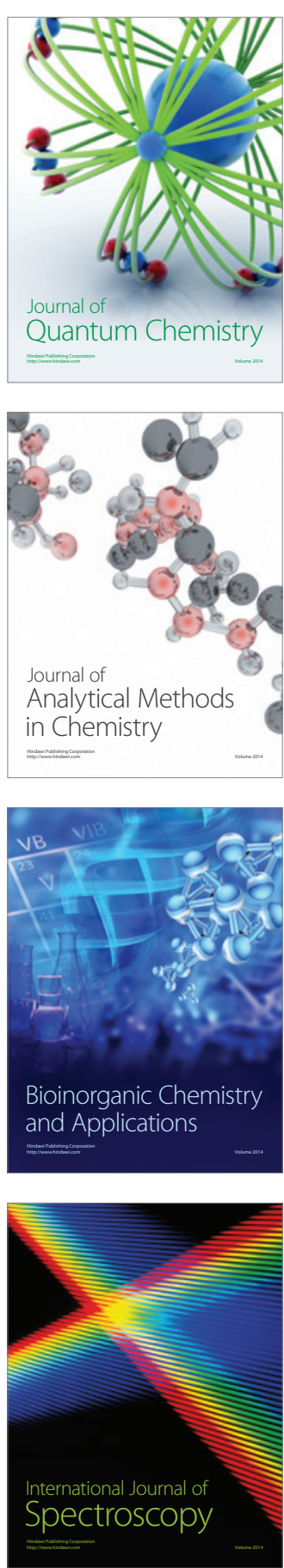